\title{
Update on the use of sildenafil in neonatal pulmonary hypertension: a narrative review of the history, current administration, and future directions
}

\author{
Zhenyu Li, Xiaoming Lv, Qinmei Liu, Dan Dang, Hui Wu \\ Department of Neonatology, The First Hospital of Jilin University, Changchun, China \\ Contributions: (I) Conception and design: Z Li, X Lv, H Wu; (II) Administrative support: H Wu; (III) Provision of study materials or patients: Z Li, X \\ Lv; (IV) Collection and assembly of data: Z Li, Q Liu; (V) Data analysis and interpretation: Z Li, D Dang; (VI) Manuscript writing: All authors; (VII) \\ Final approval of manuscript: All authors. \\ Correspondence to: Hui Wu. Department of Neonatology, The First Hospital of Jilin University, NO.71 Xinmin Street, Changchun 130021, China. \\ Email: wuhui@jlu.edu.cn.
}

\begin{abstract}
Pulmonary hypertension $(\mathrm{PH})$ is a life-threatening syndrome in neonates and has multiple and varied etiologies. However, few clinical studies have systematically evaluated the treatment regimens for this population. Phosphodiesterase (PDE) inhibitors, such as milrinone, tadalafil, dipyridamole, and sildenafil, are the most important regulators of vascular relaxation in the normal pulmonary vascular transition after birth, and these agents are widely used in the treatment of PH. Sildenafil, a representative PDE-5 inhibitor, has an important role as a single mode of therapy. However, the lack of evidence from pharmacokinetic and clinical trials has limited the emergence of standardized treatment regimens for sildenafil. There are also differing opinions among researchers regarding the best route of sildenafil administration. Due to the interindividual variability in the neonatal population, it is worth selecting the most suitable route of sildenafil administration according to the specific conditions of the neonatal population. These may be evaluated using the oxygenation index (OI), pulmonary artery pressure, mean blood pressure, and the serological index. This article reviews the clinical data on the use of sildenafil, focusing on the current and promising alternative routes of administration, which may affect subsequent clinical research in term and preterm neonates.
\end{abstract}

Keywords: Neonates; pulmonary hypertension (PH); sildenafil; route; dose

Submitted Oct 09, 2020. Accepted for publication Feb 21, 2021.

doi: $10.21037 / \mathrm{tp}-20-277$

View this article at: http://dx.doi.org/10.21037/tp-20-277

\section{Introduction}

Pulmonary hypertension $(\mathrm{PH})$ is a frequently occurring complication in neonates with high risk factors such as intrauterine hypoxia, congenital diaphragmatic hernia $(\mathrm{CDH})$, bronchopulmonary dysplasia (BPD), respiratory distress syndrome (RDS), and meconium aspiration syndrome (1-3). Therefore, it is necessary to better understand the current treatment regimens for neonatal $\mathrm{PH}$.

Inhaled nitric oxide (iNO) remains the gold standard for the treatment of persistent $\mathrm{PH}$. However, there are some shortcomings with the use of iNO: (I) it is not available in many medical facilities due to its high cost;
(II) approximately $40 \%$ of patients have no response to iNO (4); and (III) hemodynamic instability after inhalation of NO may lead to an inability to discontinue treatment or rebound $\mathrm{PH}$ (4-6). Although novel iNO donor drugs that significantly decrease pulmonary vascular resistance (compared to iNO itself) have been developed in recent years, these drugs have only been studied experimentally in animal models, and their safety and efficacy in humans are unknown $(7,8)$. Therefore, other treatments are urgently needed to address above conditions.

These treatments include systemic and inhaled vasodilators such as phosphodiesterase (PDE)-5 inhibitors, 
prostaglandins, the PDE-3 inhibitor milrinone, and endothelin (ET)-1 receptor antagonists (9). Prostaglandins and milrinone are effective therapeutic options in neonates with $\mathrm{PH}$, but there is a lack of clinical trials evaluating the efficacy and long-term sequelae of these agents in neonates $(10,11)$. PDE-5 inhibitors include dipyridamole, zaprinast, pentoxifylline, tadalafil, and sildenafil. Dipyridamole has a significant systemic vasodilatory effect, which causes systemic hypotension; however, zaprinast, tadalafil, and pentoxifylline have not been adequately studied (11-13). Sildenafil has been widely studied in neonatal animal models and neonatal populations as an off-label drug, and it is one of the first medications recommended for use in neonatal $\mathrm{PH}$. Sildenafil improves pulmonary vasodilation via activation of cGMP-dependent protein kinase and inhibition of calcium influx through the L-type calcium channel in vascular smooth muscle cells $(14,15)$. A mechanism in which sildenafil modulates the synthesis of hydrogen sulphide $\left(\mathrm{H}_{2} \mathrm{~S}\right)$ and cell proliferation in pulmonary arterial smooth muscle cells by affecting the enzymes cystathionine $\gamma$-lyase (CSE) and cystathionine- $\beta$-synthase has recently been proposed (16). In summary, sildenafil provides benefit in both the respiratory (increased oxygen index) and circulatory (increased peripheral blood volume) systems, which result in acute improvement in ventilation perfusion.

The first report of successful application of sildenafil for neonatal PH was published in the early 2000s. Kleinsasser et al. demonstrated the pulmonary vasodilator properties of enteral sildenafil in adult pig models with significant increases in intrapulmonary shunt flow (17). Subsequent studies gradually extended the applicable population to include adults, children, and neonates. Baquero et al. was the first to examine the feasibility of this treatment in the newborn population using a small, randomized, placebo-controlled pilot study in which oxygenation index (OI) was improved and the subsequent survival rate was substantially increased (18). Later, randomized controlled trials also confirmed the efficacy of sildenafil, and then studied interventions including sildenafil $v s$. placebo or no treatment, sildenafil $v s$. another pulmonary vasodilator, and sildenafil and another pulmonary vasodilator $v s$. another pulmonary vasodilator or placebo $(12,19)$. The role of sildenafil has been examined in more clinical retrospective studies to improve $\mathrm{PH}$ treatments, but there is no clear guidance regarding the choice of a specific route of sildenafil administration, with the current route of administration being more empirical or experimental.
Various medical units have tried different routes of sildenafil administration, including intravenous, oral, inhalable, and sublingual routes, which may produce different effects. However, there is currently no consensus regarding the best route of administration of sildenafil. The present narrative review provides the reader with information on the history of sildenafil for neonatal $\mathrm{PH}$, current sildenafil practices with reported outcomes, and future directions, and evaluates the advantages and disadvantages of the different modes of administration. For the review of outcomes, we have included clinical studies that were completed in neonates with $\mathrm{PH}$ and that are available in English or with English translation. We present the following article in accordance with the Narrative Review reporting checklist (available at http://dx.doi. org/10.21037/tp-20-277).

\section{Optimal dose and route of sildenafil administration for PH}

\section{Oral sildenafil}

Oral sildenafil was the first route of administration introduced, and is used worldwide. The generally accepted dose of $0.5-2.0 \mathrm{mg} / \mathrm{kg} 4$ times daily up to a maximum of $8 \mathrm{mg} / \mathrm{kg} / \mathrm{day}$, is based primarily on expert opinions and case reports $(20,21)$.

\section{Oral sildenafil in term neonates}

Beghetti et al. performed a systematic review on the use of oral sildenafil in the neonatal population prior to 2014 (22), and we have added relevant retrospective studies published in recent years $(4,23,24)$ (Table 1$)$. Notably, no improvement in the oxygen index over 36 hours $(\mathrm{P}<0.05)$ may be an independent predicting risk factor for mortality (4), which suggests the importance of comparing the various indicators before and after taking sildenafil over time. Some randomized and quasi-randomized controlled trials of sildenafil compared with a placebo or other pulmonary vasodilators have also assessed the safety and efficacy of oral sildenafil. We selected controlled trials over approximately 10 years, and the sample criteria for most studies were term or near-term neonates with persistent $\mathrm{PH}$, excluding congenital anomalies (25-31) (Table 1).

\section{Oral sildenafil in preterm neonates}

The application of sildenafil therapy in preterm neonates has generally been limited to $\mathrm{PH}$ that is secondary to BPD, 
Table 1 Characteristics of included studies in term neonates

\begin{tabular}{|c|c|c|c|c|c|}
\hline Study & Study design & $\begin{array}{l}\text { GA (weeks) } \\
(\text { mean } \pm \text { SD) }\end{array}$ & $\begin{array}{l}\text { PA at start of } \\
\text { treatment (hours) } \\
\text { (mean } \pm \text { SD) }\end{array}$ & Dose of sildenafil & Results of sildenafil group \\
\hline $\begin{array}{l}\text { Sayed } \\
\text { et al. (23) }\end{array}$ & 27 sildenafil & $40.3 \pm 1.0$ & $14.6 \pm 6.3$ & $1-2 \mathrm{mg} / \mathrm{kg}$ Q6 h & $\begin{array}{l}\text { Better oxygenation parameters, no } \\
\text { significant short-term complications }\end{array}$ \\
\hline $\begin{array}{l}\text { Alnemri } \\
\text { et al. (24) }\end{array}$ & 10 sildenafil & $37.6 \pm 2.6$ & 3.6 & $\begin{array}{c}0.3-1 \mathrm{mg} / \mathrm{kg} \\
\mathrm{Q6-8} \mathrm{h}\end{array}$ & Responded well \\
\hline \multicolumn{6}{|l|}{$\mathrm{RCT}$} \\
\hline $\begin{array}{l}\text { Al Omar } \\
\text { et al. (25) }\end{array}$ & $\begin{array}{l}13 \text { sildenafil with iNO vs. } \\
11 \text { placebo with iNO }\end{array}$ & $\begin{array}{c}38.1 \pm 1.23 \text { vs } \\
39 \pm 1.61\end{array}$ & $\begin{array}{c}12.30 \pm 11.0 \text { vs. } \\
19.54 \pm 16.6\end{array}$ & $2 \mathrm{mg} / \mathrm{kg}$ Q6 h & $\begin{array}{l}\text { No meaningful statistical difference at } \\
\text { any time point }\end{array}$ \\
\hline $\begin{array}{l}\text { Soliz } \\
\text { et al. (27) }\end{array}$ & $\begin{array}{l}29 \text { sildenafil vs. } \\
20 \text { placebo }\end{array}$ & N/A & $\mathrm{N} / \mathrm{A}$ & $2 \mathrm{mg} / \mathrm{kg}$ Q6 h & $\begin{array}{l}\text { Better oxygenation parameters, } \\
\text { decreased duration of mechanical } \\
\text { ventilation, lower mortality }\end{array}$ \\
\hline $\begin{array}{l}\text { Uslu } \\
\text { et al. (28) }\end{array}$ & $\begin{array}{c}31 \text { sildenafil vs. } \\
34 \text { intravenous } \mathrm{MgSO}_{4}\end{array}$ & $\begin{array}{c}38.5 \pm 1.6 \text { vs } \\
38 \pm 3.17\end{array}$ & $\mathrm{~N} / \mathrm{A}$ & $0.5-2 \mathrm{mg} / \mathrm{kg}$ Q6 h & $\begin{array}{l}\text { Decreased duration of mechanical } \\
\text { ventilation, no difference in mortality, } \\
\text { Significant decreased in PAP }\end{array}$ \\
\hline $\begin{array}{l}\text { Kahveci } \\
\text { et al. (29) }\end{array}$ & $\begin{array}{l}27 \text { sildenafil vs. } \\
20 \text { inhaled iloprost }\end{array}$ & $\begin{array}{c}39.23 \pm 0.9 \text { vs. } \\
39.89 \pm 1.1\end{array}$ & $\mathrm{~N} / \mathrm{A}$ & $0.5-2 \mathrm{mg} / \mathrm{kg}$ Q6 h & $\begin{array}{l}\text { Decreased PAP, improved systemic } \\
\text { hypotension }\end{array}$ \\
\hline
\end{tabular}

GA, gestational age; PA, postnatal age; SD, standard deviation; Retro, retrospective study; $\mathrm{RCT}$, randomized controlled trial; $\mathrm{MgSO}_{4}$, magnesium sulfate; OI, oxygen index; PAP, pulmonary artery pressures.

which generally occurs at a much later age (21). A systematic review and some retrospective studies have shown that, in the treatment of BPD-associated $\mathrm{PH}$, sildenafil can reduce pulmonary artery pressure and improve respiratory score (32-39) (Table 2). Some recent studies have suggested that the early prophylactic use of sildenafil in preterm neonates at a high risk of BPD can reduce the possibility of developing BPD; however, 2 randomized controlled trials did not support this hypothesis $(40,41)$ (Table 2).

\section{The pharmacokinetics of oral sildenafil}

The maximal plasma concentrations of oral sildenafil in neonates are reached within $0.5-1.5$ hours with $40 \%$ bioavailability (42). Ahsman et al. included 11 neonates who received $0.5 \mathrm{mg} / \mathrm{kg}$ of sildenafil 3 or 4 times daily via a nasogastric tube, and the dose was titrated up to a maximum of $10 \mathrm{mg} / \mathrm{kg} /$ day (20). They found that all of the neonates with an average plasma concentration area under the curve over 24 hours $\left(\mathrm{AUC}_{24}\right.$, sildenafil + metabolite of sildenafil) $>2,650 \mathrm{ng} / \mathrm{h} / \mathrm{mL}$ survived. Notably, enteral administration of sildenafil resulted in a higher rate of conversion to metabolites than the other routes of administration, but the relatively small sample size may make it impossible to explain the pronounced variability in the absorption of sildenafil and its metabolites (43). However, the efficacy of oral sildenafil had a potential relationship with the plasma concentration of sildenafil although there was high variability in the maximal dose, the number of days 
Table 2 Characteristics of included studies in preterm neonates

\begin{tabular}{|c|c|c|c|c|c|c|}
\hline Study & Study design & $\begin{array}{l}\text { GA (weeks) } \\
\text { (range/mean } \\
\quad \pm \mathrm{SD} \text { ) }\end{array}$ & $\begin{array}{l}\text { PA at start of sildena } \\
\text { (days), median } \\
\text { (range/IQR) }\end{array}$ & $\begin{array}{l}\text { Duration of sildenafil } \\
\text { (days), median } \\
\text { (range/IQR) }\end{array}$ & Dose & Results of sildenafil group \\
\hline $\begin{array}{l}\text { Nyp } \\
\text { et al. (34) }\end{array}$ & Retro & 23-33 & $167[82-307]$ & $\mathrm{N} / \mathrm{A}$ & $\begin{array}{l}0.25-0.5 \mathrm{mg} / \mathrm{kg} \\
\text { Q6 h }\end{array}$ & $\begin{array}{l}\text { Decreased PAP but little effect } \\
\text { on pulmonary gas exchange }\end{array}$ \\
\hline $\begin{array}{l}\text { Wardle } \\
\text { et al. (36) }\end{array}$ & Retro & $24-28$ & $69[32,157]$ & $77.5[6,257.5]$ & $0.5 \mathrm{mg} / \mathrm{kg}$ Q6 h & Decreased systolic PAP \\
\hline $\begin{array}{l}\text { Qasim } \\
\text { et al. (37) }\end{array}$ & Reto & $24-27$ & $77[63,112]$ & 28 & $\leq 2 \mathrm{mg} / \mathrm{kg}$ Q6 h & Reducing myocardial stress \\
\hline $\begin{array}{l}\text { Kadmon } \\
\text { et al. (39) }\end{array}$ & Retro & $23-31$ & 134 & $\mathrm{~N} / \mathrm{A}$ & $\begin{array}{l}1-2 \mathrm{mg} / \mathrm{kg} \\
\mathrm{Q} 6-8 \mathrm{~h}\end{array}$ & Improvement in Ross class \\
\hline $\begin{array}{l}\text { König } \\
\text { et al. (40) }\end{array}$ & $\begin{array}{l}\text { RCT (sildenafil } \\
\text { vs. placebo) }\end{array}$ & $24.7 \pm 0.7$ & 7 & 28 & 1 mg/kg Q8 h & $\begin{array}{l}\text { No difference in the short-term } \\
\text { respiratory outcomes }\end{array}$ \\
\hline $\begin{array}{l}\text { Abounahia } \\
\text { et al. (41) }\end{array}$ & $\begin{array}{l}\text { RCT (sildenafil } \\
\text { vs. placebo) }\end{array}$ & $24-29$ & $<1$ & 7 & $0.5 \mathrm{mg} / \mathrm{kg}$ Q6 h & $\begin{array}{l}\text { No benefits in the prevention } \\
\text { of BPD or death }\end{array}$ \\
\hline
\end{tabular}

GA, gestational age; PA, postnatal age; IQR, interquartile range; SD, standard deviation; Retro, retrospective study; RCT, randomized controlled trial; PA, postnatal age; PAP, pulmonary artery pressures; BPD, bronchopulmonary dysplasia.

to achieve this maximal dose, and the duration of therapy. Therefore, the minimum effective plasma concentration would be the key point of future research and may help to determine whether to continue sildenafil treatment.

\section{Intravenous sildenafil}

The U.S. Food and Drug Administration approved the intravenous formulation of sildenafil in 2009. This type of administration is generally used in critically ill patients in developed countries. Mukherjee et al. performed the first known pharmacokinetic trial in which the population pharmacokinetics of sildenafil in term neonates was examined. In all, 36 term neonates received intravenous sildenafil within 72 hours of birth, and the dosing regimen consisted of a loading infusion of fixed duration, ranging from 5 minutes to 3 hours to reach the target concentration in a reasonable time, and a continuous maintenance infusion of variable duration ranging from 2.6 to 168 hours was used to maintain a more stable plasma concentration $(44,45)$. This regimen became the basis for the use of intravenous sildenafil by neonatologists and in future research.

\section{Intravenous sildenafil infusion in term neonates}

There are two main types of intravenous infusion: continuous intravenous infusion and intermittent intravenous infusion.

Steinhorn et al. performed a dose-escalation trial that was based on previous pharmacokinetic studies and involved 36 near-term and term neonates (postnatal age 17-51 hours). A loading dose of $0.4 \mathrm{mg} / \mathrm{kg}$ was delivered over 3 hours followed by a maintenance infusion of $1.6 \mathrm{mg} / \mathrm{kg} / \mathrm{day}$, and the target plasma concentration was achieved with greater short-term and sustained improvement in oxygenation (46). The safety of this dosing regimen has been verified via pharmacokinetic modelling of intravenous sildenafil in neonates with $\mathrm{CDH}$ (47). Kipfmueller et al. reviewed 26 neonates (postnatal age $\leq 24$ hours) with $\mathrm{CDH}$ who received the same sildenafil dosing regimen, and observed that approximately $40 \%$ of neonates showed persistent improvement in oxygenation (48). A retrospective 
review involving 9 term neonates (postnatal age 7-33 days) with $\mathrm{CDH}$ who received continuous intravenous sildenafil $(100-290 \mu \mathrm{g} / \mathrm{kg} / \mathrm{h})$ after CDH repair reported that the OI and fraction of inspired oxygen $\left(\mathrm{FiO}_{2}\right)$ were significantly reduced, and the ratio of right-to-left to left-to-right patent ductus arteriosus (PDA) flow decreased over the subsequent 96 hours (49). However, previous studies have focused only on the short-term improvements. In future prospective studies, the long-term effect of continuous intravenous infusion or the beneficial effects beyond improved oxygenation should be investigated. Notably, an open-label, multicentre, randomized controlled trial evaluating the efficacy and safety of intravenous sildenafil compared with iNO treatment is ongoing (50).

Stultz et al. reported the outcomes of 2 full-term neonates with $\mathrm{PH}$ after $\mathrm{CDH}$ repairs who received 0.4 $-2 \mathrm{mg} / \mathrm{kg}$ of sildenafil every 6 hours. The infusion time ranged from 1 to 3 hours and showed increased oxygenation and decreased respiratory support periods (51). The retrospective, matched - cohort analysis from Darland et al. verified the feasibility of intermittent intravenous sildenafil in neonates, and found that $30 \%$ of neonates receiving intravenous sildenafil required a hypotension intervention compared to $10 \%$ in the other cohort, but there was no statistically significant difference $(\mathrm{P}=0.24)$ (45). However, the limitations of this study, including its retrospective nature and small sample size, suggest that the conclusion of the study may not be correct. Some scholars have found that the occurrence of hypotension has a certain correlation with the infusion rate. The hypotensive effects seemed to occur most commonly during relatively rapid loading infusions administered over 5 to 30 minutes, especially at higher dose levels. Furthermore, slower loading infusion administered over 3 hours at the highest dose level was not found to cause hypotension (44). Therefore, when choosing an infusion regimen, slower loading and continuous infusions should be considered to avoid adverse effects.

\section{Intravenous sildenafil in preterm neonates}

At present, very few studies have reported the outcomes of intravenous sildenafil in premature and low birth weight neonates, as it is now generally accepted that the incidence rate of $\mathrm{PH}$ in preterm neonates is much lower than that of term neonates. Notably, intravenous preparations have not been widely used in clinical practice in these populations, and there are few studies on this route of administration in preterm neonates. Intravenous sildenafil (loading dose of
$0.1 \mathrm{mg} / \mathrm{kg}$ over 45 minutes, followed by a continuous infusion of $0.5-1.2 \mathrm{mg} / \mathrm{kg} /$ day) was used to rescue of 6 critically ill extremely preterm neonates suffering from $\mathrm{PH}$, and sildenafil seemed to effectively correct the hemodynamic instability (52).

\section{The pharmacokinetics of intravenous sildenafil}

Mukherjee et al. performed a study of the population pharmacokinetics of intravenous sildenafil, which emphasized the rapid maturation of metabolic clearance in the early postnatal period, and found that the sildenafil clearance tripled at 7 days of age, which may have been attributed to the rapid maturation of cytochrome $\mathrm{P} 450$ 3A4 (CYP3A4) and CYP2C9 (44). Thakkar et al. showed that the median metabolite-to-parent ratio was higher in neonates receiving co-medications that induced CYP enzymes, and Gonzalez et al. demonstrated that enzyme inhibitors, such as fluconazole, could be used to increase plasma concentrations $(43,53)$, which provides additional evidence for the above speculations. Future research can further determine the most appropriate dose by measuring the value of the CYP enzymes and the plasma concentration of sildenafil, and dynamically monitoring the above indicators to adjust the dose and reduce side effects. Co-medications to decrease the risk of adverse events and observe whether there is a correlation between the specific CYP enzyme levels and the occurrence of adverse reactions can be applied in future.

\section{Promising alternative routes of sildenafil administration}

\section{Inbalable sildenafil}

Martell et al. established a piglet model of PH induced by meconium aspiration and found that intratracheal sildenafil was linked to a rapid decrease in mean pulmonary arterial pressure (54). Inhalable sildenafil has the ability to overcome the limitations of intravenous and oral administration routes, such as short dosing intervals and systemic adverse events. Studies, especially animal experiments evaluating the feasibility of aerosolized formulations of sildenafil, are ongoing. Rashid et al. reported the effect of a poly-lacticco-glycolic acid (PLGA) particle-based formulation of sildenafil in hypoxia-induced $\mathrm{PH}$ rat models and monitored the sildenafil pharmacokinetics in these rats. The authors demonstrated that inhalable sildenafil showed promising 
Table 3 Sildenafil use during neonatal pulmonary hypertension: route, dose, and summary of evidence

\begin{tabular}{|c|c|c|c|c|}
\hline \multirow{2}{*}{ Route } & \multicolumn{2}{|l|}{ Dose } & \multirow{2}{*}{ - Advantages } & \multirow{2}{*}{ Disadvantages } \\
\hline & Term & Preterm & & \\
\hline \multirow[t]{2}{*}{ Oral } & $0.5-2 \mathrm{mg} / \mathrm{kg}$ & $\begin{array}{l}0.3-1 \mathrm{mg} / \mathrm{kg} \\
\text { Q6-8h }\end{array}$ & $\begin{array}{l}\text { - Exert little to no effect on systemic } \\
\text { hemodynamics }\end{array}$ & - Less effective than IV route \\
\hline & Q6-8 h & & - Easier to prepare and obtain & $\begin{array}{l}\text { - Plasma concentration is erratic } \\
\text { which results in inadvertent } \\
\text { overdosing or underdosing }\end{array}$ \\
\hline \multirow[t]{2}{*}{$\begin{array}{l}\text { IV continuous } \\
\text { infusion }\end{array}$} & $\begin{array}{l}0.4 \mathrm{mg} / \mathrm{kg} \text { load over } 3 \mathrm{~h} \\
\text { with maintenance } \\
\text { infusion at } 1.6 \mathrm{mg} / \mathrm{kg} / \mathrm{d}\end{array}$ & $\begin{array}{l}0.25-0.5 \mathrm{mg} / \mathrm{kg} \\
\text { Q6-8h }\end{array}$ & $\begin{array}{l}\text { - Preferred route and seem to be more } \\
\text { efficacious than other routes }\end{array}$ & $\begin{array}{l}\text { - Random controlled trials in } \\
\text { neonates are urgently needed }\end{array}$ \\
\hline & & & $\begin{array}{l}\text { - Linked to a more predictable clearance } \\
\text { and volume of distribution compared to oral } \\
\text { capsules }\end{array}$ & \\
\hline $\begin{array}{l}\text { IV intermittent } \\
\text { infusion }\end{array}$ & \multicolumn{2}{|c|}{ 0.4-2 mg/kg over 1-3 h, Q6 h } & $\begin{array}{l}\text { - The occurrence of hypotension has a } \\
\text { certain correlation with the infusion rate }\end{array}$ & \\
\hline \multirow[t]{2}{*}{ Sublingual } & \multirow{2}{*}{\multicolumn{2}{|c|}{$4 \mathrm{mg} / \mathrm{kg}, \mathrm{Q} 6 \mathrm{~h}$}} & $\begin{array}{l}\text { - An obvious increase in effective } \\
\text { oxygenation index }\end{array}$ & $\begin{array}{l}\text { - Limited evidence compared to } \\
\text { IV route and oral route }\end{array}$ \\
\hline & & & - The most convenient route & \\
\hline Inhalable & \multicolumn{2}{|c|}{$\begin{array}{l}\text { Not recommended (animal experience } \\
\text { stage) }\end{array}$} & - Potential development & - Very limited evidence \\
\hline
\end{tabular}

IV, intravenous.

results for dose reductions and longer dosing intervals (55). Novel inhalable sildenafil citrate spray-dried microparticles have been successfully implemented, and their safety has been verified through in vitro and in vivo studies, which revealed that the drug was easily deposited in the lungs and prolonged the elimination half-life (56). However, the intratracheal administration of sildenafil is still in the animal experiment stage, and it has not been clinically tested. As a substitute for the oral and intravenous forms of sildenafil, inhalable sildenafil has broad prospects for the treatment of neonatal $\mathrm{PH}$.

\section{Sublingual sildenafil}

A case report described a term neonate with structural cardiac and pulmonary defects accompanied by symptomatic $\mathrm{PH}$ and found that sublingual administration $(4 \mathrm{mg} / 2 \mathrm{~mL}$ small syringe four times daily) substantially increased sildenafil exposure (57), most likely due to rapid mucosal absorption and partial bypass of first-pass metabolism.
Sublingual administration offers the possibility of an obvious increase in the effective OI (1); however, more trials are required to better assess the safety and efficacy of this method.

In conclusion, sildenafil for neonatal PH may be given via four routes: the intravenous, oral, inhalable, and sublingual routes. We have summarized the optimal dose, advantages, and deficiencies of each route of sildenafil administration from the available literature (Table 3). There is a scarcity of human neonatal term and preterm sildenafil data, especially from pharmacokinetic studies, which are urgently needed to identify the optimal indications, timing, dose, and routes to sildenafil in neonatal $\mathrm{PH}$.

\section{Adverse effects of sildenafil use in neonates}

We must also consider whether the advantages of sildenafil treatment outweigh its side effects in individual patients. The high selectivity of sildenafil makes it more prone to PDE-5 inhibition, but it also inhibits PDE-1, PDE-6, 
and PDE-11 to a lesser extent. Among these 3 receptors, PDE-6 receptors are present in rod and cone cells of the retina. A cohort of term and preterm neonates exposed to sildenafil was found not to exhibit a correlation with ocular complications, and these results did not support the necessity of a routine ophthalmological examination (58-61). A recent study compared a sildenafil group to a control group in preterm neonates with $\mathrm{BPD}$, and found that neonates in the sildenafil group had a higher prevalence of severe retinopathy of prematurity (ROP) than the control group; however, there was no statistically significant association (62). A large multicentre trial is needed to resolve this controversy.

Sildenafil is a vasodilator that likely acts on the whole body to cause transient hypotension. Neonates with $\mathrm{PH}$ generally have a distinct right-to-left shunting across the foramen ovale or ductus arteriosus, and sildenafil infusion may promote hypotension via direct delivery to the systemic vascular system (46). Recently, a large, novel sildenafil exposure-safety study involving 232 hospitalized neonates reported that neither dosing nor exposure was associated with systemic hypotension in a multivariable analysis (63). However, hypotension is more common with intravenous than with oral sildenafil, and it may be of clinical significance to evaluate this adverse effect in a retrospective study of intravenous sildenafil.

In general, it is necessary to monitor for adverse events at all times in the treatment of neonatal PH. If sildenafil is not tolerated, a lower dose or switching to an alternative therapy should be considered.

\section{Conclusion and perspective}

Sildenafil for neonatal PH may be administered via four routes: the intravenous, oral, inhalable, and sublingual routes. This review indicates that intravenous sildenafil may be the preferred route of administration. The lack of randomized controlled trials in the contemporary literature means that the observed clinical improvements may not be directly attributed to sildenafil, and more large multicentre randomized controlled trials should help to resolve this controversy. Randomized controlled trials on the different routes of administrations, such as oral $v s$. intravenous sildenafil or oral vs. sublingual sildenafil, should be performed regardless of sample size. Taking the advantages of the intravenous formulation into account, more neonatologists should try to use intravenous sildenafil treatment in different critical neonates. Recent studies on the application of inhalable sildenafil in animal models have indicated a potential for the use of this administration route in clinical practice. The pharmacokinetics of sildenafil and its primary metabolite in neonates have not been well studied, and the optimal doses used in different routes of administration must be examined in the future.

\section{Acknowledgments}

We would like to thank all colleagues who contributed to this study and AME Editing Service for the language service.

Funding: The study is funded by grants from the Department of Finance of Jilin Province, China (Grant Number: JLSCZD2019-012).

\section{Footnote}

Reporting Checklist: The authors have completed the Narrative Review reporting checklist. Available at http:// dx.doi.org/10.21037/tp-20-277

Conflicts of Interest: All authors have completed the ICMJE uniform disclosure form (available at http://dx.doi. org/10.21037/tp-20-277). The authors have no conflicts of interest to declare.

Ethical Statement: The authors are accountable for all aspects of the work in ensuring that questions related to the accuracy or integrity of any part of the work are appropriately investigated and resolved.

Open Access Statement: This is an Open Access article distributed in accordance with the Creative Commons Attribution-NonCommercial-NoDerivs 4.0 International License (CC BY-NC-ND 4.0), which permits the noncommercial replication and distribution of the article with the strict proviso that no changes or edits are made and the original work is properly cited (including links to both the formal publication through the relevant DOI and the license). See: https://creativecommons.org/licenses/by-nc-nd/4.0/.

\section{References}

1. Simonca L, Tulloh R. Sildenafil in Infants and Children. Children (Basel) 2017;4:60.

2. Thornton PD, Campbell RT, Mogos MF, et al. Meconium aspiration syndrome: Incidence and outcomes using 
discharge data. Early Hum Dev 2019;136:21-6.

3. Snoek KG, Reiss IK, Greenough A, et al. Standardized Postnatal Management of Infants with Congenital Diaphragmatic Hernia in Europe: The CDH EURO Consortium Consensus - 2015 Update. Neonatology 2016;110:66-74.

4. Hussain AS, Ali R, Ahmed S, et al. Oral Sildenafil Use In Neonates With Persistent Pulmonary Hypertension Of Newborn. J Ayub Med Coll Abbottabad 2017;29:677-80.

5. Dhillon R. The management of neonatal pulmonary hypertension. Arch Dis Child Fetal Neonatal Ed 2012;97:F223-8.

6. Molloy S, McVea S, Thompson A, et al. In the child with pulmonary hypertension, does treatment with enteral sildenafil compared with a slow wean from nitric oxide alone prevent rebound pulmonary hypertension and allow for discontinuation of nitric oxide?. Arch Dis Child 2020;105:410-2.

7. Stene Hurtsén A, Zorikhin Nilsson I, Dogan EM, et al. A Comparative Study of Inhaled Nitric Oxide and an Intravenously Administered Nitric Oxide Donor in Acute Pulmonary Hypertension. Drug Des Devel Ther 2020;14:635-45.

8. Nahar K, Rashid J, Absar S, et al. Liposomal Aerosols of Nitric Oxide (NO) Donor as a Long-Acting Substitute for the Ultra-Short-Acting Inhaled NO in the Treatment of PAH. Pharm Res 2016;33:1696-710.

9. Lakshminrusimha S, Mathew B, Leach CL. Pharmacologic strategies in neonatal pulmonary hypertension other than nitric oxide. Semin Perinatol 2016;40:160-73.

10. Fuloria M, Aschner JL. Persistent pulmonary hypertension of the newborn. Semin Fetal Neonatal Med 2017;22:220-6.

11. Martinho S, Adao R, Leite-Moreira AF, et al. Persistent Pulmonary Hypertension of the Newborn: Pathophysiological Mechanisms and Novel Therapeutic Approaches. Front Pediatr 2020;8:342.

12. Kelly LE, Ohlsson A, Shah PS. Sildenafil for pulmonary hypertension in neonates. Cochrane Database Syst Rev 2017;8:CD005494.

13. Jiang D, Tan H, Zhang R, et al. Borneol-mediated vardenafil hydrochloride patch for pediatric pulmonary arterial hypertension: Preparation, characterization and in vivo study. Int J Pharm 2020;591:119864.

14. Singh A, Kumar BS, Alam S, et al. Diethyl-4,4'dihydroxy-8,3'-neolign-7,7'-dien-9,9'-dionate exhibits antihypertensive activity in rats through increase in intracellular cGMP level and blockade of calcium channels.
Eur J Pharmacol 2017;799:84-93.

15. Porta NF, Steinhorn RH. Pulmonary vasodilator therapy in the NICU: inhaled nitric oxide, sildenafil, and other pulmonary vasodilating agents. Clin Perinatol 2012;39:149-64.

16. Yao Z, Wang C. A Novel Mechanism of Sildenafil Improving the Excessive Proliferation and H2S Production in Pulmonary Arterial Smooth Muscle Cells. J Cardiovasc Pharmacol 2019;74:355-63.

17. Kleinsasser A, Loeckinger A, Hoermann C, et al. Sildenafil modulates hemodynamics and pulmonary gas exchange. Am J Respir Crit Care Med 2001;163:339-43.

18. Baquero H, Soliz A, Neira F, et al. Oral sildenafil in infants with persistent pulmonary hypertension of the newborn: a pilot randomized blinded study. Pediatrics 2006;117:1077-83.

19. Perez KM, Laughon M. Sildenafil in Term and Premature Infants: A Systematic Review. Clin Ther 2015;37:2598607.e1.

20. Ahsman MJ, Witjes BC, Wildschut ED, et al. Sildenafil exposure in neonates with pulmonary hypertension after administration via a nasogastric tube. Arch Dis Child Fetal Neonatal Ed 2010;95:F109-14.

21. Wardle AJ, Wardle R, Luyt K, et al. The utility of sildenafil in pulmonary hypertension: a focus on bronchopulmonary dysplasia. Arch Dis Child 2013;98:613-7.

22. Beghetti M, Wacker Bou Puigdefabregas J, Merali S. Sildenafil for the treatment of pulmonary hypertension in children. Expert Rev Cardiovasc Ther 2014;12:1157-84.

23. Sayed A, Bisheer N. Outcome of oral sildenafil in neonatal persistent pulmonary hypertension of non-cardiac causes. J Neonatal Perinatal Med 2015;8:215-20.

24. Alnemri AM. Black lung persistent pulmonary hypertension of the newborn. Saudi experience with sildenafil and nitric oxide. Saudi Med J 2017;38:97-100.

25. Al Omar S, Salama H, Al Hail M, et al. Effect of early adjunctive use of oral sildenafil and inhaled nitric oxide on the outcome of pulmonary hypertension in newborn infants. A feasibility study. J Neonatal Perinatal Med 2016;9:251-9.

26. Vargas-Origel A, Gomez-Rodriguez G, AldanaValenzuela C, et al. The use of sildenafil in persistent pulmonary hypertension of the newborn. Am J Perinatol 2010;27:225-30.

27. Soliz A, Concha E, Romero F. Oral sildenafil treatment as therapy for persistent pulmonary hypertension of the newborn: a multicenter randomized trial. Pediatric Academic Societies Annual Meeting, 2009. 
28. Uslu S, Kumtepe S, Bulbul A, et al. A comparison of magnesium sulphate and sildenafil in the treatment of the newborns with persistent pulmonary hypertension: a randomized controlled trial. J Trop Pediatr 2011;57:245-50.

29. Kahveci H, Yilmaz O, Avsar UZ, et al. Oral sildenafil and inhaled iloprost in the treatment of pulmonary hypertension of the newborn. Pediatr Pulmonol 2014;49:1205-13.

30. Fatima N, Arshad S, Quddusi AI, et al. Comparison Of The Efficacy Of Sildenafil Alone Versus Sildenafil Plus Bosentan In Newborns With Persistent Pulmonary Hypertension. J Ayub Med Coll Abbottabad 2018;30:333-6.

31. El-Ghandour M, Hammad B, Ghanem M, et al. Efficacy of Milrinone Plus Sildenafil in the Treatment of Neonates with Persistent Pulmonary Hypertension in ResourceLimited Settings: Results of a Randomized, Double-Blind Trial. Paediatr Drugs 2020;22:685-93.

32. van der Graaf M, Rojer LA, Helbing W, et al. EXPRESS: Sildenafil for bronchopulmonary dysplasia and pulmonary hypertension: a meta-analysis. Pulm Circ 2019;9:2045894019837875.

33. Mourani PM, Sontag MK, Ivy DD, et al. Effects of longterm sildenafil treatment for pulmonary hypertension in infants with chronic lung disease. J Pediatr 2009; 154:37984.e3842.

34. Nyp M, Sandritter T, Poppinga N, et al. Sildenafil citrate, bronchopulmonary dysplasia and disordered pulmonary gas exchange: any benefits? J Perinatol 2012;32:64-9.

35. Tan K, Krishnamurthy MB, O'Heney JL, et al. Sildenafil therapy in bronchopulmonary dysplasia-associated pulmonary hypertension: a retrospective study of efficacy and safety. Eur J Pediatr 2015;174:1109-15.

36. Wardle AJ, Connolly GM, Stonier T, et al. Sildenafil in bronchopulmonary dysplasia: safe to use? Arch Dis Child Fetal Neonatal Ed 2015;100:F369.

37. Qasim A, Dasgupta S, Aly AM, et al. Sildenafil Use in the Treatment of Bronchopulmonary Dysplasia-Associated Pulmonary Hypertension: A Case Series. AJP Rep 2018;8:e219-22.

38. Trottier-Boucher MN, Lapointe A, Malo J, et al. Sildenafil for the Treatment of Pulmonary Arterial Hypertension in Infants with Bronchopulmonary Dysplasia. Pediatr Cardiol 2015;36:1255-60.

39. Kadmon G, Schiller O, Dagan T, et al. Pulmonary hypertension specific treatment in infants with bronchopulmonary dysplasia. Pediatr Pulmonol 2017;52:77-83.
40. König K, Barfield CP, Guy KJ, et al. The effect of sildenafil on evolving bronchopulmonary dysplasia in extremely preterm infants: a randomised controlled pilot study. J Matern Fetal Neonatal Med 2014;27:439-44.

41. Abounahia FF, Abu-Jarir R, Abounahia MF, et al. Prophylactic Sildenafil in Preterm Infants at Risk of Bronchopulmonary Dysplasia: A Pilot Randomized, Double-Blinded, Placebo-Controlled Trial. Clin Drug Investig 2019;39:1093-107.

42. Karatza AA, Bush A, Magee AG. Safety and efficacy of Sildenafil therapy in children with pulmonary hypertension. Int J Cardiol 2005;100:267-73.

43. Gonzalez D, Laughon MM, Smith PB, et al. Population pharmacokinetics of sildenafil in extremely premature infants. Br J Clin Pharmacol 2019;85:2824-37.

44. Mukherjee A, Dombi T, Wittke B, et al. Population pharmacokinetics of sildenafil in term neonates: evidence of rapid maturation of metabolic clearance in the early postnatal period. Clin Pharmacol Ther 2009;85:56-63.

45. Darland LK, Dinh KL, Kim S, et al. Evaluating the safety of intermittent intravenous sildenafil in infants with pulmonary hypertension. Pediatr Pulmonol 2017;52:232-7.

46. Steinhorn RH, Kinsella JP, Pierce C, et al. Intravenous sildenafil in the treatment of neonates with persistent pulmonary hypertension. J Pediatr 2009;155:841-7.e1.

47. Cochius-den Otter SCM, Kipfmueller F, de Winter BCM, et al. Pharmacokinetic modeling of intravenous sildenafil in newborns with congenital diaphragmatic hernia. Eur J Clin Pharmacol 2020;76:219-27.

48. Kipfmueller F, Schroeder L, Berg C, et al. Continuous intravenous sildenafil as an early treatment in neonates with congenital diaphragmatic hernia. Pediatr Pulmonol 2018;53:452-60.

49. Bialkowski A, Moenkemeyer F, Patel N. Intravenous sildenafil in the management of pulmonary hypertension associated with congenital diaphragmatic hernia. Eur J Pediatr Surg 2015;25:171-6.

50. Cochius-den Otter S, Schaible T, Greenough A, et al. The CoDiNOS trial protocol: an international randomised controlled trial of intravenous sildenafil versus inhaled nitric oxide for the treatment of pulmonary hypertension in neonates with congenital diaphragmatic hernia. BMJ Open 2019;9:e032122.

51. Stultz JS, Puthoff T, Backes C Jr, et al. Intermittent intravenous sildenafil for pulmonary hypertension management in neonates and infants. Am J Health Syst Pharm 2013;70:407-13. 
52. Steiner M, Salzer U, Baumgartner S, et al. Intravenous sildenafil i.v. as rescue treatment for refractory pulmonary hypertension in extremely preterm infants. Klin Padiatr 2014;226:211-5.

53. Thakkar N, Gonzalez D, Cohen-Wolkowiez M, et al. An opportunistic study evaluating pharmacokinetics of sildenafil for the treatment of pulmonary hypertension in infants. J Perinatol 2016;36:744-7.

54. Martell M, Blasina F, Silvera F, et al. Intratracheal sildenafil in the newborn with pulmonary hypertension. Pediatrics 2007;119:215-6; author reply216.

55. Rashid J, Patel B, Nozik-Grayck E, et al. Inhaled sildenafil as an alternative to oral sildenafil in the treatment of pulmonary arterial hypertension (PAH). J Control Release 2017;250:96-106.

56. Shahin HI, Vinjamuri BP, Mahmoud AA, et al. Design and evaluation of novel inhalable sildenafil citrate spraydried microparticles for pulmonary arterial hypertension. J Control Release 2019;302:126-39.

57. Carls A, Winter J, Enderle Y, et al. Substantially increased sildenafil bioavailability after sublingual administration in

Cite this article as: $\mathrm{Li}$ Z, Lv X, Liu Q, Dang D, Wu H. Update on the use of sildenafil in neonatal pulmonary hypertension: a narrative review of the history, current administration, and future directions. Transl Pediatr 2021;10(4):998-1007. doi: $10.21037 /$ tp-20-277 children with congenital heart disease: two case reports. J Med Case Rep 2014;8:171.

58. Kehat R, Bonsall DJ, North R, et al. Ocular findings of oral sildenafil use in term and near-term neonates. $\mathrm{J}$ aapos 2010;14:159-62.

59. Samiee-Zafarghandy S, van den Anker JN, Laughon MM, et al. Sildenafil and retinopathy of prematurity risk in very low birth weight infants. J Perinatol 2016;36:137-40.

60. Fang AY, Guy KJ, Konig K. The effect of sildenafil on retinopathy of prematurity in very preterm infants. $J$ Perinatol 2013;33:218-21.

61. Dunn HP, Kim LN, Popat H, et al. Ophthalmic findings in neonates receiving sildenafil. J Paediatr Child Health 2020;56:884-8.

62. Aboudi D, Swaminathan N, Brumberg H, et al. Sildenafil and Retinopathy of Prematurity in Preterm Infants with Bronchopulmonary Dysplasia. J Pediatr 2018;199:16-21.

63. Hornik CP, Onufrak NJ, Smith PB, et al. Association between oral sildenafil dosing, predicted exposure, and systemic hypotension in hospitalised infants. Cardiol Young 2018;28:85-92. 